\title{
Sobre la ineficacia del acto administrativo declaratorio de derechos
}

\author{
por \\ JOSE LUIS GONZALEZ-BERENGUER URRUTIIA
}

Secretario de $x .^{a}$ categoría y Diplomado en Administración local.

Sumario: I. Introduccion: 1. Ambito del estudio. 2. Puntualizaciones: A) La dialéctica movilidad-inmovilidad. B) La dialéctica verdad material-seguridad. C) El caso particular del acto que declara derechos.-II. EL SISTEMA LEGAL ESPAÑol: 1. La suspensión: A) Concepto. B) Supuestos: a) La actuación del órgano tutelador o ejecutor. b) La interposición de recurso gubernativo. 2. La anulación y la revocación. Criterios diferenciales: A) La anulación: 1. Esfera local. 2. Esfera central: a) Planteamiento. b) Cuadro legal. c) Algunos problemas que plantea el cuadro precedente: $\left.a^{\prime}\right)$ El acto inexistente. $\left.b^{\prime}\right)$ El trato legal indiferenciado para el acto declaratorio y el no declaratorio de derechos, en los casos de nulidad absoluta. 3. ${ }^{\circ}$ Enfrentamiento de las esferas central y local. B) La revocación. 3. La alteración de la totalidad del sistema por el artículo 112 de la Ley de Procedimiento administrativo.

\section{INTRODUCCION}

\section{AMBito DEL ESTUdio.}

La Administración emana actos para que éstos produzcan los efectos que les son propios. No obstante, por múltiples causas, el acto administrativo puede no llegar a ser eficaz.

Para encuadrar debidamente el campo de nuestro estudio, hay que decir que éste versa, sí, sobre la ineficacia del acto administrativo, mas hay que distinguir bajo esta rúbrica general, diversos supuestos que, por tener un régimen específico, no van a ser 
estudiados ahora. Entre éstos están, y creemos que con ello agotamos todos los supuestos excluidos, los siguientes:

a) El acto-administrativo-norma, que se rige por el mecanismo de la derogación (1).

b) Los actos administrativos emanados con la determinación de su revocación, si sobreviene un tercero de mejor derecho (caso de venta de parcelas sobrantes de expropiación, si después se ejercita el derecho de reversión, cuando este derecho existe (2); caso de las concesiones en general).

c) Los actos en cuya regulación está expresamente previsto el que el interés público puede justificar su retirada del mundo del Derecho (caso del rescate de concesiones, previsto en el Derecho concesional-p. ej.: artículos 125, 7, RS Corporaciones locales-; caso de la revocación de licencias, regulado por el artículo 16 del Reglamento acabado de citar) (3).

(1) La derogación del acto regla no es lo mismo que la dejación sín efecto de actos singulares; véase lo que ha dicho el Tribunal Supremo (Sala 5.a) en su sentencia de 15 de febrero de 1963.

(2) Ver GonzÁlez-BERENGUER, «Parcelas sobrantes de vía pública y partes sobrantes de expropiación», $R A P, 47$.

(3) «Es aplicable a la esfera de actuación propia de las Corporaciones locales el principio general de la irrevocabilidad per se de los actos declaratorios o constitutivos de derechos subjetivos (art. 369 de la Ley de Régimen local) compatible con la excepción referida a las licencias municipales cuando desaparecieran sus motivos, sobrevinieran nuevas circunstancias o se alteraran los criterios urbanísticos que las determinaran (art. 16 del Reglamento de 17 de julio de 1955), pero en el caso de autos el cambio de actitud del Ayuntamiento obedeció exclusivamente-según expreso reconocimiento de la Corporación autora del acto-al ejercicio de la facultad señalada en el apartado 3. del artículo 362 de la Ley de Régimen local, que impone a los Alcaldes el deber de suspender los acuerdos contrarios al orden público, supuesto que se estimó producido por el tumulto diario provocado por diversos vecinos o residentes en la barriada, contrarios a la edificación que el apelado se propuso efectuar, mas como acertadamente puntualizó el tercero de los Considerandos de la resolución apelada-anteriormente reproducida-nunca pueden transformarse las precisiones que sobre la acción jurídica de orden público, y sus concreciones especiales, aporta la legislación especial en la materia-artículos $1 .^{\circ}$ y $20^{\circ}$ de la Ley de 30 de julio de $1959-$ de tal suerte que invirtiendo los presupuestos determinantes de la acción de la autoridad, en lugar de mantener dicho orden cuando una decisión oficial sea violentamente protestada por actos incluidos en aquellos preceptos, se tome pie de tales perturbaciones ilfcitas para reputar que su promoción debe conducir a la renovación de la medida o decisión obstruidas, cuando lo lógico y lo normal es precisamente cuidar de que el motín, alga- 
d) Los actos sometidos a condición, o basados en supuestos de hecho, en los casos en que ni una ni otros se cumplen o se producen (4).

e) Los actos graciables, esencialmente revocable-p. ej.: las gratificaciones a funcionarios-(art. 87 del RF Corporaciones locales).

Por consiguiente, delimitado negativamente el ámbito de nuestro estudio, podemos ahora decir que éste se consagra al examen de la retirada del acto administrativo no normativo, en los supuestos genéricos en que dicha retirada se debe a la actuación de la Administración sobre su propio acto, actuación no sujeta a ninguna determinación específica previa. Ello constituye, con mucho, el aspecto más difícil y más interesante de este instituto (5).

\section{Puntualizaciones.}

Fijado el campo de trabajo, debemos puntualizar, antes de seguir adelante:

\section{A) La dialéctica movilidad-inmovilidad.}

Que el que la Administración pueda retirar del mundo del Derecho sus propios actos, no es cosa pacífica. Parece, por un lado, que en virtud del principio ejus est tollere cujus est condere, esta retirada del acto es posible. Nada digamos si se invoca -como es procedente hacerlo-la custodia del interés público,

rada o escándalo sean adecuadamente reprimidos mediante las medidas de policía municipal pertinentes; para que quede expedito el ejercicio de los derechos declarados o reconocidos por la Corporación; por todo lo cual las decisiones municipales revocadas por la sentencia apelada no pueden prosperar, ni por ello el recurso que se enjuicia confirmando los pronunciamientos de la sentencia de 17 de junio de 1963». (Sentencla de 4 de febrero de 1965).

(4) La irrevocabilidad presupone la no alteración de las circunstancias de hecho. Así el Tribunal Supremo en la sentencia de 21 de diciembre de 1960 . En igual sentido la de 9-IV-1949, aduciendo la desconexión entre la Administración española de uno y otro bando en la guerra civil.

(5) Cfr. DE LAUBADÈRE, Traité élémentaire de Droit administratif, 3." edición, 1963, vol. I, pág. 262. 
que puede muy bien exigir dicha retirada. Mas, por otro lado, la llamada fuerza jurídica del acto (6), para otros el principio que

(6) Sobre cosa juzgada administrativa, vid. Forsthoff, Tratado de Derecho administrativo (I. E. P., Madrid, 1958), pág. 346. Más adelante (página 355), agrupa a los autores en las siguientes categorías generales:

1) Adversarios pura y simplemente de la fuerza material de la cosa juzgada en el Derecho administrativo; por tanto, también respecto de las sentencias de los Tribunales administrativos. GNEIST, Der Rechtsstaat, página 274; ZoRN, «Kritische Studien der Verwaltungsgerichtsbarkeit», en Verw. Arch., t. II, pág. 122.

2) Adversarios de la fuerza material de cosa juzgada de los actos administrativos, pero no de las sentencias de los Tribunales administrativos; a éstos pertenecen O. MAYER, Verwaltungsrecht, t. I, págs. 162 y siguientes; JELLINEK, Verwaltungsrecht, pág. 281; KöTTGEN, Deutsche Verwaltung (3.ํ edic. 1944), pág. 222; LAFORET, Deutsches Verwaltungsrecht (1937), página 237; KOEHLER, Grundlehren des Deutschen Verwaltungsrechts (1935), páginas 186 y sigs.; IPSEN, Widerruf gültiger Verwaltungsakte (1932), páginas 46 y sigs.; KLISIN, «Zum Problem des materiellen Rechtskraft von Steuerverwaltungsakten, insfesondere von Steuerbesscheiden», en Verw. Arch., páginas 70 y sigs.; NIEMANN, "Grenzen der Rechtskraft im Steuerrecht», en Verw. Arch., págs. 135 y sigs.; RIEWALD, Reichsabgabenordnung und Steuerampassunggsgesetz, t. I, 1940, pág. 420 (los tres últimos citados, especialmente sobre Derecho tributario).

3) Admiten la fuerza material de cosa juzgada de las decisiones: BERNATZIK, Rechtssprechung und materielle Rechtskraft. Gutachen fïr den 26. Deutschen Juristentag, Verhandlungen, t. II, págs. 32 y sigs.; TEZner, «Dle Deutschen Theorien der Verwaltungsrechtslehre», en Verw. Arch., páginas 132 y sigs.; HERNTRITT, Grundlehren des Verwaltungsrechts, 1921, páginas 306 y sigs.; FrIEdRICHS, Verwaltungsrechtspflege, t. I, págs. 504 y siguientes; SCHACK, Deutsches Verwaltungsrecht, 1938, págs. 337 y siguientes; SPIEGEL, Verwaltungsrechtswissemschaft, 1909, págs. 102 y sigs.; LEDL, Verwaltungsverfahrensrecht, 1941, págs. 60 y sigs. (para el Derecho austriaco); CoEsTER, Die Rechtskraft der Staatsakte, 1927, págs. 38 y siguientes; Schultzenstern, en Verw. Arch., t. II, págs. 382 y sigs. (estos dos, limitándose a los recursos de jurisdicción); BECKER, Reichsabgabenordnung, 7." edic., 1930, observación preliminar al \& 217; BUHLeR, Lehrbuch des Steuerrechts, t. I, págs. 398 y sigs.; KLoss, «Rechtskraft in Steuersachen», en $S t u W$, año 4, 1925, págs. 13 y sigs. y 217 y sigs.; Tropp, StuW, 1932, páginas 54 y sigs. y 1.327 y sigs. (los cuatro últimos citados, sobre Derecho tributario).

Además de la bibliografía recogida en ForSthoff, vid.: LiEBmanN, Eficacia y autoridad de la sentencia, Buenos Aires, 1946, págs. 161 y sigs.; GoNZÁLEZ PÉREZ, La sentencia administrativa, págs. 209 a 218; «La cosa juzgada en lo contencioso administrativo», $R A P, 8$, págs. 67 a 76 . Niega en este estudio la existencia de la cosa juzgada en el acto administrativo. Asi como GaRRIDo FALLA, «Eficacia de los actos administrativos en la nueva LPA», RAP, 26, pág. 222; ZuANIACH, La cosa juzgada en el Derecho administrativo, Buenos Aires, 1952, págs. 91; MERKL, Teoría general del Derecho administrativo, Madrid, 1953, pág. 14; ANDRE, La retraite des actes administratives, París, 1943; DELBEz, «La révocation des actes administratifs», en Revue de Droit Public, 1928, pág. 463; Droulllat, Dans quelles conditions le gouvernement peut-il rapporter un decret de naturalisation, 
prohibe ir contra los actos propios (7), o el postulado-unánimemente aceptado-de la vocación de permanencia del acto administrativo, claramente recogido en nuestra Ley de Procedimiento (8), parecen llevarnos a la conclusión contraria. Se trata de

París, 1950; BIELSA, «Nociones sumarias sobre la cosa juzgada en Derecho administrativo», en Anuario del Instituto de Derecho Priblico, VI, 1945, página 67; LINARES, La cosa juzgada administrativa en la jurisprudencia de la Corte Suprema de la Nación, Buenos Aires, 1946; ANDREozZI, «Inmutabilidad y cosa juzgada en el acto administrativo», en La Ley, t. 47, página 998; «La cosa juzgada tributaria», en Revista de Derecho Público, Tucumán, año II, enero 1950, págs. 7-22; GaLLAND, «Conditions auxquelles il y a retrait d'une acte administratif», en Juris-classeur periodique, 1951; LACCARRIERE, Le retrait d'un acte administratif irregulier, París, 1919; LEFAS, «Retrait des actes individuels», en Etudes et Documents, París, 1949, pág. 72; FORTI, «In tema di effeti del giudicato amministrativo», en Foro Italiano, 1931, III, pág. 310; RANINCESCO, «La révocation des actes administratifs», en Mélanges Paul Negulesco, del «Institut Royal des Sciences Administratifs de Roumanie», 1935; GuICCIARDI, «I limiti soggetivi del giudicato amministrativo», en Giurisprudenza Italiana, 1941, III, pág. 17; WALINE, «L'erreur de fait, est-elle un motif legal de retrait des actes administratifs ayant cree des droits?», en Revue de Droit Public, 1951, pág. 889; Légitimité du retrait d'une décision obtenue par fraude, París, 1951; BrEWER CARIAS, Las instituciones fundamentales del Derecho administrativo y la jurisprudencia venezolana, tesis doctoral, Caracas, 1964, págs. 46 y sigs.; Royo Villanova, "Consideraciones sobre la fuerza de cosa juzgada de las sentencias de los historiales contencioso-administrativos», en Estudios en homenaje a Gascón y Marin, pág. 619; RAGGI, «Appunti sulla cosa giudicata derivanti dalla decisioni giurisdizionali amministrativa», en Foro Italiano, 1931, III, pág. 221; y también «I limiti soggetivi dell'efficacia cosa giudicata delle decisioni delle giuridizioni amministrative», en Giurisprudenza de la Corte di Cassazione, 1948, pág. 418.

(7) Sobre actos propios vid.: LOPEZ ROD0, «Presupuestos subjetivos para la aplicación del principio que prohibe ir contra los actos propios», $R A P, 9$, página 14. En contra, GarCÍA DE ENTERRÍA, «La doctrina de los actos propios y el sistema de la lesividad», $R A P, 20$, pág. 72. Dice que esta doctrina no es aplicable a la revocación y la anulación, porque se predica de conductas y no de actos. LOPEZ DE HARO, «LOS actos propios en la jurisprudencia del T. S.», en Revista de Derecho Privado, 1913, págs. 18 y 19. PUIG BRUTAU, «Actos propios», en Nueva Enciclopedia Juridica Seix, Barcelona, 1950, págs. 348-351, y en Estudios de Derecho Comparado, «La doctrina de los actos propios», Barcelona, 1951.

El Tribunal Supremo, sobre la doctrina de los actos propios ha insistido en las sentencias de 2 de febrero, 21 de noviembre y 2 de diciembre de $1959 ; 10,20$ y 23 de mayo, y 12 de junio de 1961; 20 y 30 de marzo, y 21 de noviembre de 1962. La sentencia de 27 de marzo de 1963 aplica también el principio a los actos del administrado.

El Consejo de Estado también ha abordado este punto en dictámenes tales como el de 6 de junio de 1945 (expediente 993/839).

(8) Ver Ley de Procedimiento administrativo, artículos 50 (desconexión), 51 (conversión), 53 (convalidación), 54 (subsanación). Sobre este punto con- 
uno de los puntos más controvertidos del Derecho administrativo. $Y$ lo prueba el hecho de que haya sido estudiado en trabajos publicados, prácticamente, por todos los estudiosos de la especialidad.

\section{B) La dialéctica verdad material-seguridad.}

En segundo lugar, si la Administración retira un acto suyo habrá prestado un servicio a la justicia, o a la eficacia (en el supuesto, que debemos admitir, de que el acto retirado constituyera un atentado a una $u$ otra), pero lo que es indudable es que, retirando el acto, se ha prestado un deservicio a la seguridad. Esto nos lleva a enmarcar el estudio en uno de los puntos clave de la problemática jurídica, constituido por el juego de los conceptos polares justicia-seguridad. Es indudable que el sistema de Derecho legal presta al ciudadano una seguridad máxima; todo lo aparente se presume legítimo, el tráfico queda garantizado, pero, indudablemente, más de una situación injusta quedará así amparada. Si frente a ello, queremos indagar en cada caso qué es lo justo, lograremos quizá la justicia, pero la inseguridad y la zozobra paralizarán la vida. Ejemplos de la dialéctica expuesta tenemos continuamente: el Registro de la propiedad hace posible, con la seguridad que crea, las transacciones inmobiliarias, pero a costa, a veces, de consagrar usurpaciones; las compraventas mercantiles causan usucapión automática a favor del comprador y hacen la cosa irreivindicable, sin ello nadie compraría nada, pero con ello una reivindicación justa queda enervada. En el caso que nos ocupa, la seguridad postula la imposibilidad para la Administración de retirar su propio acto del mundo jurídico, mas la justicia, o el interés público, pueden postular lo contrario.

C) El caso particular del acto que declara derechos.

Para el caso de actos declarativos de derechos-y hasta ahora no habíamos hablado de ellos, sino de los actos administrativos

fróntese DE LA OLIVA, Los vicios de forma de los actos administrativos, Madrid, 1963.

En materia de convalidación de actos anulables, es necesario tener en cuenta las siguientes sentencias: 28 de febrero de 1959, 3 de julio y 25 de septiembre de 1961 y 5 de febrero de 1962. 
en general (9)-juega, además, el principio de respeto a los derechos adquiridos.

Esto agrava la cuestión. $\mathrm{Y}$ si ante un acto que declara derechos la Administración pretende devenga ineficaz, aunque al sentido de la oportunidad, la legalidad o la justicia postulen su retirada, ésta, en aras de la seguridad, no podrá hacerse, en principio, libremente. La solución no puede ser otra, como vamos a ver, sino la intermedia, que logre un compromiso socialmente válido entre eficacia, justicia y seguridad.

\section{EL SISTEMA LEGAL ESPAÑOL}

Si los actos se producen para causar efectos, el que no los produzcan será cosa excepcional, y, por consiguiente, el tratamiento legal de esta inefectividad tendrá carácter restrictivo. Así es, en efecto, y ello se manifiesta a través de los siguientes institutos:

\section{LA SUSPENSIÓN (10).}

\section{A) Concepto.}

Se trata de la ineficacia temporal (11), (12) del acto. El acto

(9) «La doctrina, pensando quizá única y exclusivamente en las garantías de los administrados, perfiló el principio de la irrevocabilidad de los actos administrativos declaratorios de derechos y olvido el de la irrevocabilidad de los actos de la misma naturaleza declarativos de obligaciones.

Pero el interés público exige también que las obligaciones impuestas por su causa unilateralmente a los administrados, no puedan ser alteradas o extinguidas por las autoridades titulares del poder administrativo. Aun cuando la doctrina no reparó en el principio de la irrevocabilidad de las obligaciones administrativas, el principio vivía y vive, como hemos visto, en el Derecho positivo» (BOQUeRA, «Administración pública y transacción», REVISTA DE Estudios dE LA VIDA LOCAL, núm. 141, pág. 331).

(10) Sobre este instituto, ver: BONAUDI, Della sospensione degli atti amministrativi, 1908, pág. 77; CARGULO, La sospensione dell atto amministrativo de parte del Consiglio di Stato, Napoli, 1948; Tourdias, Le sursis a exécucution des décisions administratives, Paris, 1957; BOQUERA, «La facultad gubernativa de suspensión e impugnación de acuerdos locales», $R A P, 36$, especialmente págs. 115 y 129; P. BuRriel, La tutela provincial, Valencia, 1964, páginas 261 y sigs.

(11) En «Eficacia del acto administrativo», $R A P, 25$, pág. 17, señala GuítTa que hay un caso de suspensión in eternum (suspensión de actos locales por el Gobernador civil si nadie lo impugna).

(12) El Tribunal Supremo ha declarado ilegal la suspensión decretada sine die (sentencia de 28 de octubre de 1955). 
suspendido sigue existiendo, y hasta tanto no se anule o revoque, cabe la posibilidad de que recupere su eficacia plena.

El instituto presente, contrariamente a los que se examinarán después, viene uniformemente regulado para los actos declaratorios de derechos y para los que no lo son.

\section{B) Supuestos.}

La suspensión del acto administrativo puede tener lugar en dos casos: bien como consecuencia de la actuación de los órganos tuteladores o ejecutores, bien como consecuencia de la interposición de un recurso gubernativo o jurisdiccional frente al acto. Este último caso queda fuera de nuestro estudio, que ya hemos dicho que se circunscribe a la actuación de la Administración sobre sus propios actos.

\section{a) La actuación del órgano tutelador o ejecutor.}

De los dos primeros supuestos hay ejemplos en la LRL: el artículo 362 dice: «Los Presidentes de las Corporaciones deberán suspender la ejecución de los acuerdos de las mismas en los siguientes casos:

$\left.a^{\prime}\right)$ Cuando recaigan sobre asuntos que, según las leyes, no sean de su competencia.

b') Cuando constituyan delito.

$\left.c^{2}\right)$ Cuando sean contrarios al orden público.

d') Cuando constituyan infracción manifiesta de las leyes». (Hay un régimen específico para la suspensión de actos en materia de Haciendas locales previsto en el artículo $728 \mathrm{LRL}$ ).

Respecto a la suspensión por el órgano tutelador, el artículo 364 LRL regula la suspensión de acuerdos locales, en los supuestos previstos, y ello por obra de los Gobernadores civiles.

Debe hacerse notar que la consecuencia de la suspensión es el sometimiento del acto a la revisión jurisdiccional, con lo que se entra, respecto a su desaparición definitiva, en la esfera de la actuación de los Tribunales, excluida de nuestro estudio. Recordemos, sin embargo, que de los cuatro casos vistos, los 1,2 y 4 corresponderían a supuestos de anulación (acto ilegal), mientras 
que el 3 correspondería a la revocación (acto inoportuno). $\mathrm{Y}$ en el caso primero habría que distinguir también entre incompetencia absoluta (nulidad) y relativa (anulabilidad).

Fuera de la LRL encontramos un caso de suspensión en la prevista para la ejecución de sentencia por la LJC, y cuyo sujeto activo es el Consejo de Ministros.

\section{b) La interposición de recurso gubernativo.}

El otro supuesto en que frente a los anteriores, en que se actuaba de oficio, se actúa ahora a instancia de parte-nos lo ofrece el artículo 116 LPA, en que prevé la suspensión de los actos en vía de recurso, y por obra del órgano administrativo llamado a resolverlo, de la siguiente manera: «La interposición de cualquier recurso, excepto en los casos en que una ley establezca lo contrario, no suspenderá la ejecución del acto impugnado; pero la autoridad a quien competa resolverlo, podrá suspender, de oficio, o a instancia de parte, la ejecución del acuerdo recurrido en el caso de que dicha ejecución pudiera causar perjuicio de imposible reparación». A ello se añadió por Ley de 2 de diciembre de 1963, el caso de que en la impugnación se alegue que el acto está afectado por cualquiera de los vicios enumerados en el artículo 47 de la propia Ley, lo que conecta la suspensión con la anulación (13), conexión que también aparece en el Reglamento del Area metropolitana de Madrid (14).

\section{La aNULACión y LA REvocación. CRITERIOS Diferenciales.}

En virtud de su condición de custodiadora del interés público e intérprete del mismo, la Administración tiene, en principio, una suerte de disponibilidad sobre sus propios actos (15) de la que

(13) Ver sobre este aspecto de la reforma Guaita, La revisión de la Ley de Procedimiento administrativo, págs. 32-33.

(14) La doctrina entiende (ARIas Senosiain, MonaJ. Abadía) que aunque la Ley de Régimen local no la regule hay que admitir en esta esfera, también, la suspensión subsiguiente a un recurso.

(15) Para Guaita, en La revisión de la Ley de Procedimiento administrativo, la anulación es regla general. Mas tanto da esto como lo contrario, pues aquí «el orden de los factores no altera el producto». 
ya hemos hablado. La posibilidad de hacerla efectiva se despliega en dos institutos, fuertemente interpenetrados, y cuyo estudio constituye el cuerpo de este trabajo. Estos dos institutos son la revocación y la anulación. Para distinguirlos, se ha acudido a cinco criterios, dos de carácter formal u orgánico, y tres de carácter material. Estos criterios son:

a) La anulación es obra de órgano o persona que, en el complejo administrativo, ocupa un escalón jerárquicamente superior al de aquel de quien procede el acto anulado; la revocación, es obra del autor del acto que se revoca (16).

b) La anulación es la ineficacia del acto debida a la revisión del mismo por los órganos jurisdiccionales. La revocación es la ineficacia debida a la obra de la propia Administración.

c) La anulación procede cuando el acto está afectado por vicios que lo convierten en nulo. La revocación, cuando los vicios lo convierten en anulable.

d) La anulación procede cuando el acto está afectado de vicios de forma; la revocación, cuando los vicios afectan al fondo.

e) La anulación procede por motivos de legalidad. La revocación, por motivos de oportunidad. En el primer caso, el acto

(16) La doctrina se muestra muy vacilante en el uso de estos tecnicismos. Así, acepta las expresiones «anulación» y «revocación», GarRido Falla en \&La eficacia de los actos administrativos en la nueva Ley de Procedimiento administrativo», $R A P, 26$, pág. 221. GuICCIARDI y SANTI ROMANo añaden la abrogación para la inoportunidad sobrevenida. AlESSI, en La re. voca degli atti amministrativi, págs. 29 y 55, confirma esto. Para CaEtano, todo es revocación (Tratado, pág. 322).

Para FERNÁ NDEZ DE VeLASCO, en El acto administrativo, pág. 258, la revocación se funda en motivos de oportunidad. (Los Tribunales siempre producirán anulaciones, salvo el caso de ejercicio de la acción de lesividad fundada en causas económicas, mientras que la Administración anula unas vecés y otras confirma. En este sentido, la sentencia de 21 de abril de 1961, Sala 4.7, aunque según Royo-Problemas de régimen local, pág. 42-, el criterio jurisprudencial también era vacilante).

Para ForsthofF, la anulación de actos administrativos onerosos es en principio posible en todo momento. Nos hallamos ante la cancelación. La anulación de actos administrativos favorables se denomina revocación (Tratado de Derecho administrativo, I. E. P., 1958, pág. 357). 
es contrario al Ordenamiento; en el segundo, contrario al interés público (17).

Aunque el Derecho positivo español todavía no se hace eco de esta precisión (piénsese que el artículo 369 LRL, y el artículo 110 LPA, para referirse al mismo fenómeno, usan, respectivamente, los tecnicismo revocar y anular, así como en la fugaz alusión a la revocación contenida en la LPA), podemos considerar que en nuestro sistema hay datos bastantes para decir que el criterio es el último (18) (19).

(17) «La legalidad debe, ineludiblemente, ser la caracteristica que con mayor intensidad debe ostentar todo acto de la Administración. Mas la con. formidad de un acto administrativo con el ordenamiento jurídico no es, por si sola, índice suficiente para determinar su conveniencia y adecuación con el interés público. Así puede en realidad ocurrir que siendo un acto de la Administración perfectamente legal, sea, no obstante, inoportuno para los Intereses, económicos o de otra índole, de la entidad.

Legalidad $\mathbf{y}$ oportunidad son, en consecuencia, dos factores del acto administrativo que, aun cuando no se excluyen, tampoco necesariamente se identifican». (TRUJILlo, Quintana y Bolea, Comentarios a la ley de lo Contencioso, I, pág. 903).

(18) Bibliografía sobre anulación y revocación: O. MAYER, Derecho administrativo, Buenos Aires, 1950, t. II, págs. 50 y sigs.; RAGGI, Diritto amministrativo, t. I, págs. 160 y sigs.; DE VALLES, La validitá degli atti amministrativi, pág. 344; SANDULLI, «I limiti dell'existenza dell'atto amministrativo», en Rasegna di Diritto Pubblico, IV, 1949, pág. 125; LENTINI, "Termine di impugnata degli atti assolutamente nulli», en Nuova Rasegna di Diritto Pubblico, 1949, pág. 1.140; Giustizia amministrativa, Milán, 1949, pãg. 318; «Atti amministrativi inesistenti, nuli e annulabili», en Nuova Rasegna di Diritto Pubblico, 1952, págs. 496 y sigs.; CAMMEo, «La nullitá parziale degli atti amministrativi e le giurisdizioni di annulamento», Giurisprudenza Italiana, 1911, LII, pág. 27; ROMANELLI, L'annulamento degli atti amministrativi, Milán, 1939; RANELLETTI, Le guarantigie della giustizia nella pubblica Amministrazione, 5." edic., 1937, pág. 137; BORSI, La giustizia amministrativa, 7. ${ }^{a}$ edic., 1941, pág. 36; D'AlessIo, Istituzioni di Diritto amministrativo italiano, 1934, 1." edic., II, pág. 202; 1942, 3." edic., t. II, págs. 218 y sigs.; SALEMI, La giustizia amministrativa, 1932, pág. 18; ZANOBINI, Corso di Diritto amministrativo, I, 5." edic., 1947, pág. 252; Alonso OleA, «Lesividad y revocación de las resoluciones en materia de personal», $R A P, 14$; «La revocación de los actos administrativos en materia de personal», RAP, I; GoNZÁlez PEREz, \&La revocación de los actos en la jurisprudencia española», RAP, 1; VılLLAR PALASÍ, «La eficacia de la concesión y la cláusula sin perjuicio de tercero», RAP, 5, pág. 206; GuAITA, «La revisión en vía de agravios», en Estudios en homenaje a García Oviedo; «Revocación de actos declaratorios de derechos en materia de personal», $R L J$, marzo 1957.

(19) Sentencia de 21 de abril de 1961 (Sala 4.4): «Anular significa, tanto en el lenguaje usual como en el forense, dejar sin fuerza o eficacia operativa una disposición o acto, y ello por razones de antijuridicidad o vicio formal, y no de mera oportunidad o alteración de criterio estimativo, que son las que más frecuentemente determinan la revocación en sentido estricto». 
De aquí se sigue que, mientras la revocación es una facultad de la Administración extrínseca al acto (20), la anulación parece ser una obligación (21) de la Administración, y funciona en base a circunstancias intrínsecas al acto mismo. La Administración actúa sus potestades revocatorias a su libre arbitrio, mientras que la Administración parece estar obligada a actuar siempre que se encuentra ante un acto aun producido por ella misma que esté viciado. $\mathrm{Y}$ ello en la siguiente medida (22).

\section{A) La anulación.}

Para un estudio correcto de nuestro Derecho positivo, es preciso distinguir las dos esferas territoriales, empezando por la más rudimentariamente regulada, que es la esfera local.

\section{1.․ Esfera local.}

Traduce todo lo anterior al mundo normativo el artículo 369 LRL: «Las autoridades y Corporaciones locales no podrán revocar sus propios actos o acuerdos declaratorios de derechos subjetivos, o que hubieren servido de base a una sentencia judicial, salvo al resolver recursos de reposición. Podrán rectificarse los errores materiales o de hecho». Mas fuera de este caso-la resolución de la reposición-ideberá la Administración mantener siempre los actos declaratorios de derechos, aunque estén gravemente viciados? El instinto jurídico nos dice que no, que algún género de detención de los efectos de un acto absolutamente ilegal tiene que haber arbitrado la Ley.

No es, desde luego, solución la brindada por el artículo 4. del Código civil. Ello introduciría una grave inseguridad, ya que no

(20) Forsthoff, Tratado, pág. 359. La revocación no es lo mismo que el actus contrarius al otorgamiento. La revocación encuentra ante si una situación ya estructurada.

(21) M. REToRtillo, S. ( $\mathrm{El}$ exceso de poder como vicio del acto administrativo», $R A P, 23$, pág. 150) duda de que haya tal obligación. Parece darle la razón el artículo 112 de la Ley de Procedimiento administrativo, sobre lo cual se insistirá más adelante.

(22) Esta medida era amplisima hasta la Ley de lo Contencioso de 1894, según prueba GaRcía DE ENTERRIa ( La configuración del recurso de lesividad», $R A P, 15$, págs. 109 y sigs.), y en virtud del principio jerárquico que obligaba a anular los actos viciados emanados de un inferior. No habia más excepción que los actos emanados de los Ministros. 
toda violación de lo dispuesto en la Ley merece la grave sanción de la nulidad. No la merece en el campo civil (23), mucho menos la merecerá en el campo administrativo (24) en el que, como ha dicho Royo, la teoría de las nulidades debe ser manejada con mucha precaución (razón: el acto se presume legítimo y producido por razones de interés público en el caso de la Administración; lo lógico por ello es tender a mantenerlo con mayor vigor que en el caso civil, en el que los actos no tienen a su favor tal presunción, ni persiguen directamente el interés público).

Hay que atender, por consiguiente, al grado de gravedad de la infracción en que el acto incurra, y sólo estableciendo unos supuestos de ilegalidad extrema, estableceremos la posibilidad de una declaración de nulidad. (No podemos distinguir en esta esfera entre declaración de nulidad y anulación).

Ya antes de la aparición de la LRL (que permite, como bemos visto, la retirada del acto del mundo del Derecho al resolver el recurso de reposición, y que permite también efectos prácticos iguales en el caso de corregir errores materiales o de hecho), ya antes, decimos, el Tribunal Supremo había proclamado lícita la declaración de nulidad de actos hecha en la Administración, en caso de ilegalidad indiscutible, señaladamente en los nombramientos irregulares (cosa no infrecuente, por desgracia, en la vida local). Debemos aclarar que se trata de jurisprudencia que habla de nulidad declarada por la propia Administración, no de jurisprudencia declaratoria ella misma de nulidad, cosa que queda fuera de nuestro estudio (lógicamente, esta última jurisprudencia es abundantísima; la primera es muy escasa).

(23) Ver Castro, Derecho civil, vol. I, págs. 536 a 538.

(24) Forsthoff (Tratado, pág. 311) dice: «No es fácll declarar nulo el acto administrativo». Y en este sentido, el Tribunal Supremo, de acuerdo con el principio antiformalista, ha proclamado reiteradamente, entre otras, en la sentencia de 30 de junio de 1961 , que «no todos los defectos procesales acarrean la nulidad de las resoluciones en los que se producen, sino sólo las que surten consecuencias sustanciales».

Igualmente GARRIDO, Tratado, vol. I, pág. 424.

Véase sobre vicios de los actos administrativos y sus consecuencias en orden a la nulldad: sentencias de 23 de diciembre de 1958; 26 de febrero, 30 de abril y 26 de septiembre de 1960; 25 de enero, 18 de abril, 23 de junio, 14 de octubre y 21 de noviembre de 1961; 5 de enero, 12 de noviembre y 22 de diciembre de 1962. 
La doctrina había abundado también en igual criterio. Royo Villanova, en Problemas de régimen juridico municipal, había señalado una serie de vicios que causan nulidad absoluta, y daban lugar a la posibilidad de declarar nulo el acto afectado por ellos, en cualquier tiempo. GARRIDo, en Régimen de impugnación de los actos administrativos, perfiló aún más esta lista (en lo sustancial coincide con el actual artículo 47 LPA).

Pero es que además, que nosotros sepamos, apenas se ha prestado atención a un trascendental artículo del Reglamento de Organización y Funcionamiento de las Corporaciones locales: el 293, que dice: «Los actos o acuerdos no podrán ser anulados por defectos de trámite, salvo que sean esenciales o produzcan indefensión, en cuyos supuestos habrá de reponerse el expediente al momento procesal en que se cometió la falta» (25).

De aquí se deduce que los actos declaratorios de derechos pueden, en la esfera local, ser declarados nulos por defectos de trámite, si estos defectos son esenciales (26) o si producen indefensión. Como veremos, esta previsión no conocida en la esfera central ni siquiera ahora, da una apertura extraordinaria de posibilidades anulatorias a la Administración local. Se trata de la

(25) Si se adjudicó por acuerdo municipal al propietario colindante que lo solicitó una porción de terreno sobrante, no puede luego la Corporación dejar sin efecto dicho acuerdo a pretexto de que la parcela concedida pertenecía a otra persona.

Esta es la doctrina del Tribunal Supremo en su sentencia de 22 de febrero de 1964, diciendo que el Ayuntamiento no está facultado para volver sobre sus propios actos cuando éstos son declaratorios de derecho a favor de tercero.

Según la sentencia de 12 de marzo de 1960, la Corporaciones locales no pueden entablar la acción de nulidad o anulación de un acuerdo suyo basándose en las infracciones legales que concurrieren en él al adoptarse, ni en carecer tal acuerdo de los requisitos necesarios para adoptarlo, ni en ninguna otra causa, sino unicamente en ser lesivo para la Corporación.

La sentencia de 12 de mayo de 1960 considera improcedente el que a una licencia para edificar se agregue después la exigencla de que el titular debe pagar el alcantarillado, aduciendo para ello la sentencia, la inmodificabilidad del acto administrativo.

La sentencia de 10 de diciembre de 1962 declara no aplicable este artículo en virtud del principio que prohibe ir contra los actos propios, ya que el acto anulatorio no se apoyaba en defecto de trámite, sino en incumplimiento de condición.

(26) La sentencia de 28 de septiembre de 1957 define como esenciales sólo los trámites previstos en norma con rango de ley. 
huella del sistema universal de libre anulación-salvo para decisiones ministeriales-vigente en España hasta la implantación. como modo universal de anulación de actos declaratorios de derechos, de la lesividad (27).

Por consiguiente, el sistema en la LRL y el ROF, es el siguiente:

1.9 En principio, todo acto o acuerdo, puede ser libremente retirado, y debe ser anulado, si adolece de vicios graves.

2. Excepción de lo anterior. No pueden ser retirados los: actos declaratorios de derechos, o que sirvan de base a una sentencia judicial.

3.- Excepción de la excepción. Aunque declaren derechos, los. actos deben ser declarados nulos:

a) Al resolver el recurso de reposición (28) si se observa que. el acto estaba viciado.

b) Al corregir errores materiales o de hecho. (La corrección, naturalmente, no anula el acto, pero puede producir iguales efectos prácticos que si se anulara).

c) Al observarse que se han cometido faltas de procedimiento que producen indefensión.

4. Debe completarse el cuadro con la sumaria exposición del sistema de la lesividad, instituto del que no es éste el lugar adecuado para hablar, pero que conviene sea citado para hacer constar que siendo la lesividad un sistema mediante el cual la Administración logra la retirada del mundo jurídico de actos suyos declaratorios de derechos, mediante la petición hecha en tal sentido a los Tribunales, fácilmente se comprende que anulación o revocación por la Administración, y declaración de lesividad, son institutos incompatibles (tienen de común: el origen del acto y el propósito de la Administración de dejarlo sin efecto, mas difieren en el procedimiento para lograrlo). Esta incompatibilidad se traduce en que una ampliación de la esfera de un instituto, supone una reducción en el grado de aplicabilidad del otro.

(27) Respecto a la evidente ampliación de facultades anulatorius en la esfera local frente a la central, cfr. GARCía DE ENTERRia, «La configuración del recurso de lesividad», $R A P, 15$, págs. 135 y sigs.

(28) El Estatuto estableció lo contrario (art. 225), si bien el Tribunal Supremo lo suaviź. 
Pues bien, la lesividad había sido regulada en la LRL de manera que se exigía para declararla procedente una doble condición: que el acto fuera atentatorio a los intereses económicos, y que, además, infringiera el Ordenamiento. A partir del artículo 56 de la LJC, para la procedencia de la declaración de lesividad sólo se exige una condición: lesión a los intereses públicos, sean económicos o no (29). Esto, naturalmente, es aplicable a ambas esferas, y ha aumentado el ámbito de la lesividad, suponiendo una correlativa restricción de la esfera de la anulación de oficio (en la práctica es muy dudoso que esta reducción se haya notado, pero es que lo que en la práctica sucede es que el artículo $293 \mathrm{ROF}$ es muy poco conocido y aplicado). Pues bien-y ésta es la razón por la que la lesividad, instituto común a ambas esferas territoriales, se estudia en este momento-, esta ampliación del marco de la lesividad sólo ha tenido lugar con una cierta duración--aún perdura - en la esfera local, ya que en la central se ha sufrido, por el contrario, una fuerte reducción, como vamos a ver más adelante.

\section{2.- Esfera central.}

a) Planteamiento.-Contrariamente a lo visto para la esfera local, donde no es posible establecer una gradación en base a la entidad de los vicios que adolecen los actos, en la esfera central, recogiendo lo postulado por la doctrina, se establece una distinción entre actos afectados por vicios que pudiéramos llamar gravísimos (los enumerados en el artículo 47 LPA), y actos afectados por vicios graves $\mathrm{y}$ menos graves. Los primeros dan lugar a la nulidad, los segundos a la anulabilidad (30).

(29) Para la declaración de lesividad no se precisa la lesión de intereses económicos, pues desde la vigencia de la Ley Jurisdiccional de 1956 basta que exista cualquier clase de lesión al interés público. Así lo establece la sentencia de 4 de julio de 1964.

(30) La distinción nulidad-anulabilidad ha sido muy discutida. Para FORSTHOFF se trata de una cuestión de grado (Tratado, pág. 314). Consideran injustificada la distinción RAGGI (Diritto amministrativo, vol. I, páginas 160 y sigs., cit.); DE VALles (La validitá degli atti amministrativi, páginas 344 y sigs.); SANDULLI ( $\ll$ I limiti dell'existenza dell'atto amministrativo», en Rasegna di Diritto Pubblico, IV, 1949, pág. 125, cit.); ZANoBINI (Diritto amministrativo, vol. I, pág. 64).

Sin embargo, admiten la distinción, D'Alessio, Istituzioni di Diritto amministrativo, vol. II, págs. 231 y sigs.; VITTA, «Competenza giudiziaria 
La distinción es, sin ningún género de duda, aplicable al Derecho español, si bien, como decimos, por ahora sólo a la esfera central. Basta para ello con la lectura de los artículos 109 y 110 de la LPA, en relación con el artículo 47 y siguientes de la propia Ley. En el cuadro del texto se recoge, creemos que con fidelidad, la distinción que la LPA plantea, diferenciando el caso de acto afectado por vicios gravísimos (cuyo acto «es»nulo, y la Administración al actuar sobre él, se limita a constatar lo que ya «es», teniendo su decisión anulatoria un valor declarativo, lo que no tiene nada que ver con la necesidad de que tal decisión se produzca, como más adelante sostenemos), del caso de acto afectado por vicios graves o menos graves (cuyo acto es simplemente anulable, y la Administración ha de anularlo, dentro del plazo legal, pasado el cual deviene inconmovible). En el primer caso, la Administración lo que hace es «declarar la nulidad», en el segundo caso, lo que hace es «anular». En ambas ocasiones; la Administra-. ción-frente a la potestad revocatoria de que se hablará después y que se basa en motivos de oportunidad-está ejercitando la potestad anulatoria, que se basa, como repetidamente venimos diciendo, en motivos de legalidad, mas en este supuesto, los motivos pueden ser gravísimos (nulidad, o ejercicio de la potestad anulatoria a través de la declaración de nulidad), o simplemente graves o menos graves (anulabilidad, o ejercicio de la potestad anulatoria a través de la anulación). Esta «quasi-homonimia» resulta peligrosa, y mientras no sea sustituida por tecnicismos más diferenciados, toda insistencia como la de las presentes líneas será poca.

b) Cuadro legal.-El sistema de la potestad anulatoria en la esfera central es el siguiente (31) :

su deniego di potere discrezionale in atti amministrativi», en Giurisprudenza Italiana, 1951, I, pág. 520.

(31) El cuadro que se expone y estudia corresponde al sistema de la Administración central en general. De manera absolutamente recusable, la Ley general Tributaria ha establecido un sistema diverso, de revisión de actos en vía administrativa (arts. 153 y 154), en el que si bien por un lado se reducen los supuestos de declaracion de nulidad, por otro se amplían grandemente los de anulabilidad, suprimiéndose, además, la fuerte garantía de la intervención del Consejo de Estado, e incluso (véase art. 154) la declaracion y proceso de lesividad.

Repetidas veces hemos juzgado desfavorablemente estos olvidos que el 
1. Anulación (o ineficacia del acto por adolecer de un vicio, basada por consiguiente en razones de legalidad).

$\left.a^{3}\right)$ Si el acto no era declaratorio de derechos:

a') Actos con vicios que lo convierten en nulo ...... artículo 109.

b”) Actos con vicios que lo convierten en anulable ...... se retira libremente.

b') Si el acto era declarativo de derechos:

a’) Acto nulo ...... Disciplina del artículo 109.

Con los vicios enumerados en el artículo 47 LPA, cabe la declaración de nulidad siempre, previo dictamen del Consejo de Estado y con efectos ex tunc (32).

b') Acto anulable (la anulación, siempre, con efectos ex nunc) (33).

a'”) Por vicios de ilegalidad manifiesta (34):

legislador padece, de que en España existe una magnifica Ley de Procedimiento, a la que, o se la da carácter universal en nuestra vida jurídica. - no sirve para nada. Esta regulación ad hoc de la revisión de actos, es uno de estos condenables olvidos, olvidos en los que incurre con frecuencia la legislación hacendística.

(32) Esto parece abrir la posibilidad de que los Tribunales examinen la legalidad de los actos, sin sujeción a plazos. Vid. sentencia de 21 de octubre de 1960, citada por BOQUERA en La seleccion de contratistas (I. E. P., 1953, pág. 203). En igual sentido también la O. M. del Ministerio de Educación de 10 de mayo de 1954, citada por GARCía DE ENTERRÍa en «Recurso contencioso directo frente a disposiciones reglamentarias» $(R A P, 29$, página 179), donde dice que la impugnación de estos actos está exenta de la carga de agotar la vía administrativa.

En contra, sentencia de 2 de junio de 1944, citada por Garrido Falla en «Los motivos de impugnación del acto administrativo», en $R A P, 17$, página 25; y el Consejo de Estado (dictamen 25656 de 26 de noviembre de 1960) ha dicho que el artículo 109 sólo es aplicable de oficio, y que los particulares no tienen otra vía que la de los recursos.

Sobre este trascendental punto, véase últimamente TRUJILlo, Quintana, BoleA, Comentarios... I, pág. 912. Suscribimos íntegramente esta opinión.

(33) El procedimiento de anulación, frente al de declaración de nulidad:

a) Se inicia siempre de oficio (sobre lo inadecuado del enunciado del capítulo correspondiente de la Ley de Procedimlento administrativo, cfr. GoNzÁlez PÉREz, El procedimiento..., pág. 707). b) Caso de prosperar, produce efectos ex nunc, $y c$ ) Tiene un plazo para ser promovido.

(34) La sentencia de 26 de enero de 1961 declara aplicable el artícu1o 110 de la Ley de Procedimiento administrativo en casos de actos decla- 


\author{
Cabe la anulación, si no han pasado cuatro \\ años y previo dictamen del Consejo de Estado. \\ b"') Por vicios de ilegalidad no manifiesta (35): \\ Cabe la anulación, si no han pasado cuatra \\ años y previa declaración de lesividad.
}

rativos de derecho, si la vulneración de la norma es «manifiesfa; esto es, descubierta y patente, de suerte que aparezca por la mera confrontación del contenido del acto con el precepto que lo regula, sin necesidad de acudir a la interpretación o la exégesis». Concluye la sentencla aplicando el artículo 112 de la Ley de Procedimiento administrativo. Sobre este punto, confróntese Clavero Arévalo, «La manifiesta ilegalidad de los actos administrativos», REvista DE Estudios DE LA VIDA LOCAL, núm. 102, págs. 832-845.

GaRcía-Trevijano (Tratado de Derecho administrativo, t. I, pág. 300) dice: «Al exigirse para el segundo caso que la ilegalidad sea manifiesta, se ha extendido la opinión errónea de que existe otra clase de ilegalidad «no manifiesta», la cual daría lugar al supuesto tercero de revocación (mediante declaración de lesividad por y ante los Tribunales).

Esta gradación de ilegalidades es absurda. Una ilegalidad-contrario a derecho un acto-o es manifiesta o no existe... La palabra «manifiesta» no encierra un grado de la infracción, sino una terminología tradicional en el lenguaje procesal.

Para nosotros...: 1. Existe una nulidad de pleno derecho revisable de oficio, y sobre la que no existe discusion. Se trata de actos sólo aparentes, pero sin existencia en el mundo jurídico (aberraciones jurídicas). 2. Existe una ilegaíidad revisable de oficio, a través de un procedimiento, sin que la característica de ser manifiesta o no, sea concluyente para dar lugar o no a la anulación... La revisión de oficio es una potestad renunciable por la Administración, que siempre puede acudir a la lesividad... (en algunos casos será obligatorio recurrir a ella). 3. Existen, por último, infracciones cuya denuncia hay que hacerla a través del proceso de lesividad. No se trata de «simples ilegalidades», como se afirma, sino de casos especiales de ilegalidad económica y jurídica ensambladas».

(35) La sentencia de 5 de noviembre de 1962 (Sala 4.9), sobre licencia municipal de obras a vivienda de renta limitada. Legitimacion activa y actos propios, dice asi: «Considerando: Que nuestro ordenamiento jurídico administrativo al regular las potestades de la Administración respecto a sus propios actos, proyecta las de anulación o revocación de los mismos hacia casos taxativamente enumerados y ello mediante concretas garantías determinadas de manera que pueda sentarse como principio de tal carácter en esta materia, que es recogida en el artículo 37 de la Ley de Régimen juridico de la Administración del Estado de 26 de julio de 1957, y repetido en el 110 de la Ley de Procedimiento administrativo de 17 de julio de 1958, aquel. que propugna que dicha Administración no puede anularla ni revocar de oficio sus propios actos declarativos de derechos de tal guisa que, salvo en aquellos casos taxativas según ordena el numero dos del precepto en último lugar citado, para conseguir la anulación o revocación de dichos. actos, deberá la Administración acudir al proceso de lesividad impugnándolos ante la Jurisdicción contencioso-administrativa. Y ello ha de ser asi: por exigencia de la propia seguridad jurídica de los administrados». 
2. El caso de error material o corrección aritmética (36), (37). En todo momento puede ser efectuada la corrección, cualesquiera que sean sus efectos sobre la eficacia del acto (nos remitimos a lo dicho más atrás).

c) Algunos problemas que plantea el cuadro precedente.-El cuadro precedente debe completarse con una alusión al acto no notificado.

(36) Ver sentencia de 26 de febrero de 1963 (Sala $5 .^{8}$ ), sobre expropiación forzosa de finca afectada por el Plan de ordenación urbana y error de la Administración en la valoración, con reposición del expediente al trámite de ofrecimiento del precio.

La sentencia de 3 de octubre de 1960 ha dicho:

"Considerando: Que como quiera que la Administración no puede anular de oficio sus propios actos declarativos de derechos, salvo cuando dichos actos infrinjan manifiestamente la ley, según dictamen del Consejo de Estado, y no hubieren transcurrido cuatro años desde que fueron adoptados, excepto si se trata de rectificación de errores materiales o de hecho; se impone reconocer que la Orden del Ministerio del Aire de 30-IX-1959, no se limitó a rectificar errores materiales o de hecho de la dictada el día 19 del mismo mes y año, puesto que lo que hizo fue interpretar una norma jurídica, al referirse a los requisitos que habian de concurrir para que se concediese el ascenso conferido al recurrente, y tratándose de una cuestión de derecho, la Administración carecía de facultades para anular su primer acuerdo, faltando el dictamen del Consejo de Estado o la declaración de lesividad».

La sentencia de 8 de abril de 1965 ha dicho que al amparo del artículo 111 de la Ley de Procedimiento administrativo no es posible rectificar una valoración, si no se trata de error de hecho.

La sentencia de 10 de octubre de 1960 ha dicho:

«Considerando: Que en lo que atañe a la subsistencia de la Orden de 4 de abril de 1959, es un hecho el que, acertada o erróneamente, por la misma fue ascendido a Teniente el Sr. X, y por lo tanto se crearon derechos a su favor, que la Administración no puede ignorar, ya que ella los estableció, ni menos aún los puede atacar, anular o dejar sin efecto, como se pretende por las resoluciones impugnadas en estas actuaciones, pues para llevar a cabo tales actos tenía que cumplir el requisito de recurrir aquella Orden ante esta vía, como lesiva para el Estado, por lo que por no haberse seguido este camino, es obligado declarar la nulidad de la Orden recurrida».

Acerca del procedimiento de rectificación de error de hecho, GoNZÁlez PÉREZ (El procedimiento, pág. 742) hace notar la diferencia entre este procedimiento (en el que el acto rectificado subsiste) y el del artículo 127, 1, de la Ley de Procedimiento administrativo para el recurso de revisión por error de hecho. Por nuestra parte creemos erróneo establecer la diferencia en base a la subsistencia del acto.

(37) El principio del mantenimiento de los derechos reconocidos por la Administración, no juega cuando se trata de rectificar errores de hecho (sentencia de 22 de octubre de 1965, Sala 4."). 
Según doctrina jurisprudencial, dudosamente admisible, los actos pueden ser retirados, concedan o no derechos, mientras no sean notificados (38).

Concluso el cuadro, expongamos los dos principales problemas que el mismo suscita:

$\left.a^{\prime}\right) \mathrm{El}$ acto inexistente.

Como es sabido, el acto inexistente es una noción nacida para encajar sistemáticamente ciertas figuras aberrantes que aparecen en el Derecho matrimonial. No tiene nada de extraño que buena parte de la doctrina francesa-no toda, como puede observarse en las citas que más abajo se hacen-haya aceptado tal tecnicismo si se recuerda que en el vecino país (39) sólo se conocen

(38) Extremo nuevo creado por el Tribunal Supremo: el acto no notificado. La sentencia de 5 de octubre de 1961 dice:

«Considerando: Que el acto administrativo de otorgamiento de prórroga para las obras de concesión de aguas de la que es titular la Corporación recurrente, no lleg6 a originar derechos de carácter subjetivo dado que es un punto incontrovertido en la litis que no tuvo lugar su notificación, por lo que, con arreglo a los artículos 45 y 79 de la vigente Ley. de 17 de julio de 1958, no alcanzó la necesaria eficacia. Ello determina la licitud de poder ser anulado tal acto por la Administración, tanto más cuanto que no se ha llegado a hacer esto en la Orden combatida, sino sólo a dejar en suspenso el extremo relativo a la prórroga interesada, como consiguiente lógico de la suspensión de las obras que la propia Orden dispone, para volver sobre el mismo cuando éstas puedan ser reanudadas. No existe, pues, la alegada infracción del artículo 110 de la Ley procedimental administrativa vigente».

Ni que decir tiene que la sentencia transcrita es de doctrina absolutamente inadmisible. La Administración no puede tener en su mano la posibilidad de hacer lo que quiera con sus actos, sólo porque no han sido notificados. Concretamente, para la esfera local, hay obligacion taxativa de notificar en el plazo de diez días siguientes a la adopción de los acuerdos. Además, en todo caso, el administrado puede-y debe atendérsele-forzar la notificación pidiendo un certificado acreditativo de la decisión administrativa.

Este punto esperamos sea rectificado por el Tribunal Supremo, pero mientras no lo sea, hay que consignar como un elemento del sistema el «acto no notificado», e incluirlo en el cuadro de posibilidades de la Administración para retirar del mundo del Derecho los actos de que es autora. Véase sobre este punto GonZález-Berenguer, «La actividad certificante de la Administración», RAP, 38, pág. 225.

(39) Cfr. RIvero, Droit administratif, 2." edición, 1962, págs. 93 y siguientes; DELBEz, «La révocation des actes administratifs», en Rerue de Droit Public, 1928, pág. 463; WALINE, «Le retrait des actes administratifs», Mélanges Mestre, pág. 563; Jean de Soto, Contribution a la théorie des nullites des actes administratifs unilateraux, tesis doctoral, Paris, 1941; AUBY, «L'influence du changement de circonstances sur la validité des actes administratifs», en Revre de Droit Public, 1959, pág. 431; LAUBADÈRE, Droit 
dos institutos (abrogation y retrait) para los casos de acto irregular a retirar por la propia Administración. Ni uno ni otro pueden ser puestos en marcha más allá del plazo para el ejercicio de la acción contenciosa (dos meses), entendiendo que no le es posible a la Administración actuar sobre sus propios actos en un plazo superior a aquel en que podrían hacerlo los jueces. De este modo, con tan breve plazo para actuar, resultan inatacables actos absolutamente irregulares, y el único modo de evitar tal cosa es el admitir la figura de acto inexistente, cuyo plazo de retirada no tiene límite temporal. El planteamiento, como se ve, no puede ser más diverso que el que ofrece el Derecho español, con su posibilidad de retirada temporalmente ilimitada para el acto afectado de vicios gravísimos. Prácticamente, las consecuencias de la admisión de la figura del acto inexistente son obvias: a la Administración le basta con desconocerlo, sin que necesite formalidad alguna para su retirada.

Nosotros creemos que en nuestro Derecho es absolutamente inadmisible la figura del acto inexistente (40). Mucho menos te-

administratif, 3.a edición, 1963, t. I, págs. 274 y sigs:; VEDEL, Droit administratif, 1958, t. I, pág. 124.

(40) Sobre el supuesto acto inexistente, vid. sentencias de 2 de julio de 1964 y de 22 de noviembre de 1960; sentencia de la Audiencia de Zaragoza de 26 de junio de 1963; sentencias de 21 de abril de 1961 y de 21 de octubre de 1960, ambas de la Sala Cuarta del Tribunal Supremo.

El Tribunal Supremo ha dicho, sin embargo, que tales actos pueden simplemente desconocerse y ello en las siguientes sentencias:

«Ya de antiguo la doctrina viene distinguiendo entre otras figuras de invalidez de los actos jurídicos, la de nulidad absoluta ipso iure o de pleno derecho, frente a la de nulidad menos grave o mejor anulabilidad o impugnabilidad del acto defectuoso; significando ello que el acto afectado por la primera de dichas figuras de invalidez no produce en absoluto los efectos que típica o normalmente le son atribuidos, y para el ordenamiento jurídico es como si no existiera, por lo que todos obran rectamente desconocléndole, procediendo como si no hubiera tenido lugar, mientras que al acto impugnado o anulable, también defectuoso, se le puede privar de eficacia o validez, pero si quien tiene la facultad de pedir su anulación no lo hace, el acto a falta de tal reacción, y no obstante sus imperfecciones, produce sus efectos y consecuencias típicas $u$ ordinarias; distinción doctrinal que puede proyectarse sobre los actos administrativos y servir de base a la diferenciación entre actos que no son susceptibles de convalidación o consentimiento y actos que, aunque tachados por algún defecto, pueden sin embargo ser consentidos y convalidados por actitudes de aceptación o por simple renuncia o dejación de los correspondientes medios legales impug. natịivos; pero además nuestro Derecho administrativo vigente, percatado, 
ner por tal aquel al que le falta algún elemento. La más primordial seguridad jurídica exige que los actos, por viciados que estén,

sin duda, de la gravedad que supone la calificación de nulidad per se, o nulo de pleno derecho, aplicado a un acto de la Administración, no ha querido dejar tal calificación a la mera apreciación doctrinal, sino que en el artículo 47 de la Ley de Procedimiento administrativo de 17 de julio de $1958 \mathrm{se}$ ha señalado expresa y concretamente qué actos de la Administración son nulos de pleno derecho; y a tal precepto habrá que atenerse, por tanto, para saber si es correcta o no, en este punto, la tesis de la sentencia apelada» (sentencia de 7 de marzo de 1963).

«Es acto radicalmente nulo la venta de cosas comunales realizada sin observar las formalidades administrativas. Es acto que no es posible declararlo lesivo por tratarse de inexistencia de acto y solo de apariencia de acto administrativo» (sentencia de 22 de mayo de 1961).

En igual sentido, sentencia de 20 de noviembre de 1962 (Sala 4. ${ }^{a}$ ), sobre contratación de Corporaciones locales, adjudicación de terrenos y nulidad de la misma.

Por último, el Tribunal Supremo ha dicho que frente a una conducta pasiva no cabe hablar de anulacion.

«... al no prever la Ley ficción jurídica alguna sobre la admisión o impugnabilidad de éstos, la inoperancia de la Administración, evidentemente censurable, no constituye la formulación de actos positivos de género alguno que puedan invalidarse y en cuya patente negligencia podrá darse la infracción de normas jurídicas que impusieran plazos concretos y determinados para la práctica de trámites o para dictar resolución, pero cuyas vulneraciones sólo pueden dar lugar a la solicitud o exigencia de responsabilidad administrativa $y$, en algunos casos, económica en cuanto a los funcionarios negligentes, pero no viciar un procedimiento, pues para que esto ocurra es imprescindible que éste se haya seguido o cursado y que al hacerlo se hubieran omitido diligencias o provefdos esenciales cuya falta privará de garantías procesales al interesado, lo que no puede suceder en los casos en que, como en el supuesto presente, no existe tramitación alguna, sino una completa conducta pasiva que por su indole no engendra actos positivos susceptibles de error y anulación, y aunque se pueda argüir que esta pasividad administrativa es la negación implícita de toda garantía procesal..., no puede anularse lo inexistente, pues para que esta facultad sea factible ejercitarla se precisa opere sobre algún acto o acuerdo de la Administración...» (sentencia de 21 de septiembre de 1963).

Es interesante recordar a este respecto los artículos del Código penal, sobre la actuación del funcionario que desobedece un mandato ilegal, aplicables al supuesto acto inexistente y a la supuesta posibilidad de desconocerlo (arts. 369 y 370 ).

La doctrina no es aquí pacífica. Véase:

a) Autores que admiten la figura del acto inexistente:

BERIo, «Impugnativa degli atti amministrativi assolutamente nulli», en Nuova Rasegna, 1950, pág. 9. Asi como los siguientes autores (citados por Brewer Carias, él mismo partidario de la admisión de la figura de la inexistencia, en op. cit., pág. 88): AUBY, La théorie de l'inexistence des actes administratifs, tesis, París, 1946; $\mathrm{P}$. WEIL, Une resurrection: la thég l'inexistence en Droit administratif; DALLoz, Croniques, 1958, pág TRO-PASQUA, «Inconvertibilitá degli atti amministrativi inesistent del Seminario Giuridico dell' Università de Bari, 1936; F. GAZIER 
deban ser retirados del mundo del Derecho mediante unas formalidades mínimas. Se exceptúa el caso de acto no atribuíble en

«La notion d'acte administratif inexistente», en Actualité Juridique, número 38-39, 1954, pág. 5.

\&En cuanto a la extensión del principio de irrevocabilidad, es lógico que se refiere a aquellos supuestos en que el acto administrativo concesional sea válido, ya que en otro caso subsiste el poder de autoimpugnación de la Administración activa que puede incluso desconocer el acto inválido (VILLAR PALASí, «La eficacia de la concesión...», $R A P, 5$, pág. 211). En igual sentido, Delbez, «La révocation des actes administratifs», en Revue de Droit Public et de la Science Politique, 1948, núm. 45. LAFERrière, Traité de la Jurisdiction administrative, t. I, págs. 407-408.

b) Autores de tesis dudosa:

Aunque González Pérez dice que la nulidad radical, en todo tiempo y sin recurrir a órgano extraño, puede la Administración aducirla, aunque se trate de acto declaratorio (GONZÃ LEZ PEREZ, «El proceso de lesividad...», en $R A P, 25$, pág. 131-anterior a la Ley de Procedimiento administrativo-), no por ello admite la figura de la inexistencia. Cfr. El procedimiento administrativo, pág. 370.

FORSTHOFF (Tratado, pág. 166): «El acto administrativo nulo es generalmente irrelevante... El Tribunal sólo tendrá competencia para considerar un acto como no existente, cuando su nulidad sea de tal modo evidente que no necesite fundamentarse, sino simplemente sefialarse como hecho incuestionable». $\mathrm{Y}$ por el contrario, «el acto apariencia producido por un funcionario de hecho, es auténtico acto administrativo» (Tratado, pág. 317).

LAVILLA, en «La revocación de oficio de los actos administrativos», en $R A P, 33$, dice respecto a lo que él llama acto inexistente (o acto a.l que falta algún requisito esencial), que a la Administración le basta con desconocerlo.

En igual sentido, Romanelli (loc. cit., pág. 141).

c) Frente a estos tratadistas y con criterio a nuestro juicio acertado, pues la seguridad juridica exige un acto formal de retirada, pueden verse los autores siguientes:

S. LESSONA, en «Interés privado y deber de abrogar los actos administrativos ulteriormente ineficaces», en Rivista Trimestrale di Diritto Pubblico, 1952, págs. 289-308. LENTINI afirma que la inexistencia o nulidad deben ser siempre declarados; el acto administrativo despliega su eficacia en tanto no venga pronunciada la inexistencia o la nulidad ( Atti amministrativi inesistenti, nulli e annullabili», en Nuova Rasegna, año VII, núm. 7, págs. 496 y siguientes, y en el mismo sentido en «Termine di impugnata degli atti assolutamente nulli», en Nuova Rasegna, 1949, pág. 140, y en Giustizia amministrativa, Milán, 1949, pág. 318, citados en nota 18). GarRIDo . Falla, en «Los motivos de impugnación del acto administrativo», en $R A P, 17$, pág. 17, se opone a la tesis del simple desconocer.

Se opone igualmente PEREz González y Alguer: siempre hace falta que intervenga el juez (Tratado, II, pág. 362). Colin y CAPITANT, Cours de Droit civil, t. I, pág. 185, en igual sentido.

d) La actual doctrina francesa aplica a estos casos la teoría de las vías de hecho. Cfr. RIvero, Droit administratif, París, 1950, pág. 210. Y lo mismo el Conseil d'Etat. Cfr. ODENT, Contentieux administratif, 1953, página 557. 
absoluto, y según racionales criterios, a la Administración, en cuyo caso lo correcto no es hablar de acto inexistente, sino de inexistencia de acto (41).

b') El trato legal indiferenciado para el acto declaratorio y el no declaratorio de derechos, en los casos de nulidad absoluta.

En segundo lugar, debe decirse que, aunque en la práctica, el acto radicalmente nulo, si no concede derechos será retirado libremente, creemos que es deliberada la no distinción por el artículo 109 LPA entre actos declaratorios y no declaratorios de derechos (42).

A nuestro juicio, frente al acto no declarativo de derechos, las potestades de la Administración son máximas: puede retirarlo. Mas no puede retirarlo como si no hubiera existido. $\mathrm{Y}$ ello por

(41) Asi hace gran parte de la doctrina. Por todos, Sayagues, Derecho administrativo, Montevideo, 1953, t. I, pág. 505; y LAUBADÈRE, Droit administratif, 1963, vol. I, pág. 207.

(42) Encuentra Lavilla (loc. cit.), como razones que explican el que el artículo 109 hable de todos los actos, y no sólo de los declaratorios de derechos, las siguientes:

1) Que la Ley está redactada de manera que ha desaprovechado la posibilidag que se le brinda de hacer una regulación total del problema. Quizá estemos de acuerdo. Pero mientras esté redactada como está, la única interpretación posible es la que proponemos.

2) Que como se trata de actos nulos no productores de efectos, en el caso del artículo 109, no puede hablarse de derechos adquiridos al amparo de tales actos. A esto respondemos que el acto nulo, mientras no es declarado tal, también produce efectos. (Véase a este respecto: PÉREz JoFrE DE VILLEGAS, «Los poderes de la Administración para revocar de oficio sus propios actos y su posible extensión a la Administración municipal cuando sean declaratorios de derechos», en Municipalia, núm. 60).

3) Que debe distinguirse entre acto nulo y acto inexistente (al que le falta algún elemento esencial). Frente a éste basta con desconocerlo, afirma.

4) Siendo el artículo 109 aplicable también al acto-regla, puede suceder que los actos concretos y apoyados en él (en el acto-regla nulo) subsistan, siendo solamente, en ese caso, simplemente anulables (LAvilla AlsiNa, «La revisión de oficio de los actos administrativos», $R A P, 33$ ).

La opinión común se inclina por la tesis de LAviLLA, en cuanto a la interpretación a dar el trato indiscriminado que parece otorgar a toda clase de actos el artículo 109. Y razona así El artículo 110 (vicios graves) no es aplicable a los actos no declaratorios de derechos. Estos si tienen vicios graves se retiran libremente, luego con mayor razón podrán ser retirados los actos que adolezcan de vicios gravisimos (por todos, en este sentido, García Manzano, en Seminarios de la Facultad de Derecho de la Universidad de Navarra, y GONZÁLEZ PEREZ, en El procedimiento..., págs. 701 y 704) y dictamen del Consejo de Estado de 9 de junio de 1960 (Expt. número 6.311). 
dos razones: $1 .^{\mathrm{a}}$, el acto aparentemente más alejado del concedente de derechos, puede, acaso, interesar a alguien; 2. a, el principio de estabilidad. Por ello, el artículo 109 LPA, a diferencia del siguiente, no distingue entre actos que concedan o no concedan derechos, y regula, universalmente, no la anulabilidad con efectos ex nunc, sino la nulidad con efectos ex tunc; es decir, como si el acto no hubiera existido. Esto sólo es posible, naturalmente, si el acto adolece de alguno de los vicios citados en el artículo 47 LPA.

Insistimos en que esta interpretación es la única que satisface ante el hecho, a primera vista desconcertante, de que el artículo 109 LPA no distinga entre actos declarativos y no declarativos de derechos (43).

\section{3.? Enfrentamiento de las esferas central y local.}

No ofrece duda alguna que el sistema que acaba de exponerse es el que quedará en vigor el día que se adapte la LRL a la LPA, $y$ en vigor para todas las esferas (44), (45). Lo importante ahora es señalar que, en realidad, tal sistema ya está vigente casi integramente en la esfera local. Pasamos a demostrarlo.

Respecto a los casos de acto nulo, una interpretación progre-

(43) Véase GonzÁlez-Berenguer, «La ineficacia del acto administrativo», en El Consultor de los Ayuntamientos, de 10 de enero de 1963.

(44) Asi, el artículo 76 de la Ley especial de Madrid dice que el Pleno puede anular o declarar la nulidad de los actos, según lo previsto en la Ley de Procedimiento administrativo.

En la misma línea progresiva se encuentra el Reglamento para la ejecución de la Ley del Area metropolitana, que dice que tanto los Ayuntamientos comprendidos en la zona del Area como la Comisión de ésta, pueden declarar la nulidad de sus propios actos, y ello según lo previsto en la Ley de Procedimiento administrativo. Añade, muy sagazmente, que si el expediente de nulidad se inicia de oficio, su primer trámite estará constituido por la suspensión del acto.

Contrariamente a ello, y de modo inexplicable, el Reglamento de $\mathrm{Ha}$ cienda municipal de Madrid, da un paso atrás, y dice, en su artículo 118, que en materia de Hacienda, el Ayuntamiento de Madrid no podrá anular sus actos, sino sólo declararlos lesivos (ignorando ası toda la tendencia doctrinal y legislativa en sentido contrario). De modo también injustificado, declara el artículo 130 que la rectificación de errores materiales no podrá tener lugar pasados cinco años de la comisión del error. Igual tope marca la Ley general Tributaria.

(45) La sentencia de 16 de marzo de 1959 ha equiparado los articulos 47 LPA y 293 ROF. 
sista del artículo 293 del ROF, puede abarcar todos los supuestos de acto nulo del artículo 47 de la LPA, salvo el de acto delictuoso o imposible. En efecto, salvo ese caso, todos los demás del artículo 47 de la LPA pueden considerarse como defectos esenciales del procedimiento. $\mathrm{Y}$ respecto a los actos delictuosos $\mathrm{e}$ imposibles, la jurisprudencia ha declarado la posibilidad de su anulación de oficio por la Administración en alguna ocasión.

Veamos, pues, qué novedades va a introducir en el sistema local la disposición de la LPA:

Respecto al acto nulo, la necesidad de intervención del Consejo de Estado, u órgano que, para lo local, lo supla (46).

Respecto al acto anulable, la reducción del ámbito de la lesividad, que queda relegada a los casos en que el acto infrinja la ley, mas no manifiestamente. La crisis de la lesividad es hoy un hecho en nuestro Derecho; en lo local, con el artículo 293 del ROF; en la esfera central, con la reducción de que hablamos, por obra de la LPA. En la doctrina, EnTERría, demostrando que la lesividad no es un privilegio, sino una carga (47); GARRIDo, hablando de la necesidad de abrir brecha en el sistema; TreviJano, sosteniendo que la lesividad sólo procede por causas de inoportunidad o de daño económico, etc. (48), (49), (50); ENTRENA, sosteniendo que toda ilegalidad, por el hecho de ser conocida, es manifiesta (51) ; GuAITA, defendiendo que el artículo 37 de la LRJ (antecedente del artículo 110 LPA) ha acabado, prácticamente, con el proceso de lesividad (52), (53).

(46) Cfr. Galván, El Consejo de Estado en la nueva Ley municipal, Valencia, 1936.

(47) «El sistema de la lesividad...», cit.

(48) Curso de Derecho administrativo, t. I, págs. 203-204.

(49) En contra, NIETo en «Lesividad y expropiación», $R A P, 36$, pág. 140.

(50) Trujillo, Quintana y Bolea (Comentarios..., I, pág. 932) opinan y sin fundamentar, creemos, su opinión, que la lesividad no procede por motivos de carácter económico, y que «el fundamento en que la Administración ha de basar su pretensión de dejar sin efecto un acto propio es, ineludiblemente, su ilegalidad».

(51) «El proyecto de ley de revisión de la Ley de Procedimiento administrativo, de 17 de julio de 1958», en Documentación Administrativa, núm. 68.

(52) Derecho administrativo especial, t. I, pág. 178.

(53) Sobre declaración de lesividad véanse las siguientes sentencias: 31 de enero, 20 y 22 de junio, 28 de noviembre de 1959, 9 de marzo, 3 de junio, 3 y 10 de octubre, 22 de noviembre de 1960 (Sala 3.8), 22 de no- 
Respecto al acto anulable, que infrinja manifiestamente la ley, se aplicará el artículo 110, párrafo 1, de la LPA. Es indudable, por ello, que se introducirá en la esfera local la distinción nulidad-anulabilidad (54).

Quedarán con ello absorbidos todos los supuestos (menos los dos ya citados, y que deberán incorporarse expresamente a la legislación local), todos los supuestos del interesante y olvidado artículo 293 del ROF.

En ambas esferas queda, naturalmente, en vigor la posibilidad de retirar actos, como consecuencia de la interposición de ia reposición $(55),(56)$.

\section{B) La revocación.}

El problema se plantea ahora en el campo de la revocación. Como ha recordado GARCÍA DE ENTERRÍA, ésta pudo llevarse a cabo libremente hasta la inserción, en 1894, en el sistema contencioso español, del llamado recurso de lesividad, inserción que acabó con una posibilidad de siempre mantenida por la Administración, en el sentido de dicha libre revocabilidad aun frente a actos declaratorios de derechos, y en ello en virtud del principio jerárquico, que permitía al superior actuar sobre los actos del inferior (57).

Es evidente que la justicia material, o el interés público, postulan la permanencia de tal posibilidad, y a ello alude, sin duda, el artículo 119 de la LPA. Mas en el caso de no interposición de recursos (58), ¿podrá la Administración revocar de oficio sus ac-

viembre (Sala $5 .^{\mathfrak{n}}$ ), 26 de abril, 3 de octubre, 7 y 27 de diciembre de 1961 y 22 de junio de 1962 .

(54) Sobre la actual falta de matización en este punto, en la ssfera local, cfr. GONZÁ LEZ PEREZ, El procedimiento..., pág. 708.

(55) PÉrez Jofre de Villegas ( «Los poderes de la Administración para revocar de oficio sus propios actos, y su posible extensión a la Administración municipal cuando son declaratorios de derechos», en Municipalia, número 60 , cit.) considera aplicable integramente el sistema central a la esfera local.

(56) Véase González-Berenguer, «Las potestades de la Administración en el caso de interposición de recursos», en el Boletín del Colegio de Secretarios, agosto de 1965.

(57) Cfr. G. DE Enterría, «La configuración...», RAP, 15, págs. 112 y siguientes.

(58) «Es errónea la opinión que admite la posibilidad de que la Administración revoque uno de sus actos a consecuencia del recurso contra él interpuesto por un particular. Ello en nuestro Derecho no puede acaecer en 
tos inoportunos, declarativos de derechos?, ¿o bien podrá entenderse que la «lesión a los intereses públicos de carácter económico o de otra naturaleza de que habla el artículo 56 de la LJC ampara todo supuesto de inoportunidad (59), lo que ampliaría fabulosamente, contra lo ya dicho, el campo de la lesividad?, ¿o bien no habrá posibilidad alguna de revocar? La parquedad de los textos legales es aquí desconcertante (60).

forma alguna, ya que el fundamento de cualquier recurso administrativo podrá ser la infracción del Ordenamiento por el acto que se impugna (art. 115 de la Ley de Procedimiento administrativo), pero, en cambio, no existe precepto alguno que permita al administrado accionar contra un acto, apoyado exclusivamente en su supuesta inoportunidad» (TRUJILlo, QuinTANA, BolEA, Comentarios..., pág. 905).

Frente a esta tesis la sentencia de 3 de julio de 1962 (Sala 3.8), dice: «Sin que pueda oponerse válidamente a esta interpretación el hecho de que habiendo recaído, en via administrativa, el 24 de agosto de 1961 acuerdo favorable, este acuerdo sea ya intangible para la Administración que, por ello, ya no pudo ir contra sus propios actos, pues es inadmisible tal tesis en las resoluciones que se tomen en la via procesal administrativa, pues esta no se agota hasta que se dicta la última palabra en los recursos definitivos, de alzada o de reposición, correspondiendo la jurisdicción al superior jerárquico para que éste pueda, libremente, acordar lo que es procedente sin la limitación de que ya no pueda cambiar de parecer respecto del que fue formulado subordinadamente, porque esto significaría negar de plano todo el sistema procesal administrativo».

(59) «No basta con la mera existencla de alguna infraccion jurídica en las actuaciones administrativas que precedieron al acuerdo cuya declaración de lesividad se postula, para que automáticamente se produzca ésta, lo que desnaturalizaría el preciso ámbito de la lesividad, sino que es preciso que concurra una «lesión de los intereses públicos».

Abundando en el acertado criterio del Tribunal a quo, debe recordarse que no basta con la mera existencia de alguna infracción juridica en las actuaciones administrativas que han precedido al acuerdo municipal cuya declaración de lesividad se postula, para que automáticamente se produzca ésta, lo que desnaturalizaría el preciso ámbito de la lesividad, sino que es preciso que concurra una «lesión de los intereses públicos», cuya representación, defensa y gestión, correspondería a la Corporación recurrente, en la que el rasgo inicial del quebrantamiento de norma vaya acompañada por algún daño o perjuicio concreto para esos intereses, ya sea de naturaleza económica, ya de otra indole; daño o perjuicio que tampoco debe identificarse con la diferencia entre el mayor acierto y beneficio que para las Corporaciones puedan concebirse en el desarrollo de sus relaciones de contratación con los particulares, y los resultados posiblemente menos favorables que dentro del correspondiente marco legal se hayan producido por el encarecimiento de su proyecto de obras, luego modificado y objeto de revisión imperativa de precios». (Sentencia de 30 de septiembre de 1963).

(60) «El primer lapsus lo comete el legislador, en la Exposición de Motivos. Tras decir que, por primera vez en nuestro Ordenamiento, se pretende distinguir, al analizar las potestades de la Administración respecto de sus propios actos, entre nulidad, anulacion, rectificación de errores y revo- 
Nosotros nos inclinamos, aun conscientes de los graves peligros que de aquí se derivan para la seguridad jurídica, por la primera solución, es decir, la tradicional hasta la universalización de la lesividad (61). El modo de obviar los peligros dichos no es otro que la utilización pronta y ágil de ulteriores recursos jurisdiccionales con plenos poderes de control de hechos y de motivaciones en manos de los Tribunales (62).

La única vía legal hábil para ello hoy en España es la de la Ley de Expropiación forzosa (63), cuya aplicación a todos los

cación, comete la inconsecuencia de explicar a continuación el significado de los tres primeros, sin que vuelva a acordarse de la revocación, cuando tan sencillo hubiera sido dedicarle un breve párrafo para delimitar su contenido.

La segunda omisión se descubre ya en el articulado. Se echa en falta un nuevo artículo que, comprendido entre los actuales 110 y 111, viniera a decir que la Administración puede revocar en cualquier momento sus propios actos cuando, aun sin infringir el ordenamiento jurídico, se estimen inoportunos o contrarios al interés general» (TruJILlo, QUINTANA, BoleA, Comentarios..., pág. 906).

(61) En contra, Ortolá Navarro en su conferencia La tensión Poderlegalidad (Peñíscola, 1966), cuya tesis se resume en sus últimas lapidarias palabras: nulla anulatio sine jurisdictio.

(62) «En principio, debe estimarse como normal la potestad de la Administración de revocar sus propios actos que, por cualquier razón y aun a pesar de no infringir el Ordenamiento, devengan inoportunos, como medio para lograr que, en todo momento, su actividad se moldee a las fluctuaciones que el interés público (concepto dinámico), experimente... la libertad de revocación no significa que las autoridades pueden usarla según su libre arbitrio, pues la arbitrariedad es absolutamente incompatible con el derecho; antes bien, la revocación debe ser medio que sirva al interés público que le está confiado al ente; la revocación presupone, por tanto, un motivo objetivo» (Trujillo, Quintana, Bolea, Comentarios..., pág. 905).

(63) Una vez que la Administración ha declarado el derecho del particular no puede pretenderse su revocación alegando razones de utilidad pública, precisando acudir a otras soluciones, como la expropiación forzosa. Así lo dice el Consejo de Estado: «Nuestro Derecho administrativo no conoce una virtualidad permanente de los motivos que los haga actuar a modo de presupuesto interesse publico sic stante, sino que, por el contrario, elimina la relevancia de este superior interés público, una vez que la Administración ha declarado el derecho del particular, definitiva o condicionalmente. La supervivencia de razones de utilidad pública no autoriza a la Administración, salvo el caso de reserva expresa, una vez pasada la fase de la estimación discrecional, a destruir lo otorgado o revocar lo concedido, sino que precisa acudir a otras soluciones, como la expropiación forzosa, que sin imponer tal revocación, hagan posible la consecución del superior interés público». (Dictamen del Consejo de Estado de 28 de junio de 1952, exp. p. 329).

La inmutabilidad del acto administrativo alcanza no solamente al propio acto en cuanto declaración de voluntad, sino también a la interpretación que 
supuestos concebibles resulta de una violencia patente. Pero no es imposible hacerlo. Y lo más deseable de todo sería la implantación del sistema que conoció la letra impresa, aunque no en el «Boletín Oficial», cuando se preparaba la Ley de Procedimiento. Es el único concebible para una Administración viva y dinámica, Administración que ha de estar plenísimamente sometida a un control jurisdiccional, que no se limite a la legalidad, sino que abarque, como el del Consejo de Estado francés, todos, absolutamente todos, los aspectos de los actos (64).

al mismo se dio por la Administración. Así lo dice el Consejo de Estado: «La inmutabilidad del acto administrativo no solamente se refiere al propio acto en cuanto a declaración de voluntad, sino también a la interpretación que al mismo en la operación material se dio por la Administración. Esta tesis es consecuencia obligada del principio de inmutabilidad del acto que, de otra forma, podría fácilmente frustrarse por vía de interpretación o corrección de hecho. Esta interpretación variada no es en definitiva sino la aclaración o rectificación de un error de hecho, en el caso de que se hubiera producido, $y$ es visto que la jurisprudencia utiliza, respecto a la variación, por razón de error de hecho, la tesis que propugna la invariabilidad del acto transcurrido a los cuatro años desde su emanación». (Dictamen de 1 de mayo de 1953, exp. 11.641).

(64) Royo, en Problemas... (pág. 45), dice: «A los derechos adquiridos hay que poner también un límite, y éste es el interés público. Por consiguiente, los Ayuntamientos podrán tomar en el ejercicio legítimo de las funciones que les competen las medidas que exijan el interés y la seguridad públicos. Si con ocasión de la política urbana y de seguridad se lastiman situaciones juridicas nacidas al amparo de acuerdos anteriores, no por eso son nulos los acuerdos tomados en el ejercicio de inexcusables deberes y funciones. Los derechos de los particulares no pueden tener un carácter intangible y perpetuo. Ello supondría la renuncia de los Ayuntamientos al cumplimiento de sus fines; implicaría la enajenación de su potestad. Ahora bien, en estos casos hay que reconocer a los particulares el derecho a la indemnización correspondiente, ya que, en realidad, existe una verdadera expropiación de derechos por causa de utilidad pública». Las palabras de Royo pueden aplicarse a la Administración en general: los famosos derechos adquiridos-de los que Duguit dijera que nunca ha sabido nadie en qué consisten-, no pueden paralizar la acción administrativa. Obsérvese, por otra parte, la amplitud con que el sistema-no obstante su falta de reconocimiento en bloque como tal-es hoy de aplicación en el Derecho español. Recuérdense, sin ánimo exhaustivo, además de la previsión respecto a licencias municipales, contenida en el artículo 16 del Reglamento de Servicios de las Corporaciones locales (y las licencias municipales suponen la mitad del intervencionismo administrativo) y la regulación del rescate de concesiones (uno y otro institutos fueron citados al comienzo de este trabajo), la suspensión indefinida del contrato de obras, como causa de resolución del mismo (arts. 52 y 53 de la Ley de Contratos del Estado de 8 de abril de 1965), la extinción del contrato de servicios (arts. 75 y 79 de la propia Ley), etc. En todos estos institutos y otros más que podrian citarse, aparece una auténtica retirada, por obra de la Administración (fundada en motivos de interés 
Este sistema venía regulado de manera general, como acabamos de decir, en el proyecto de la LPA; se instauraba la posibilidad de retirada universal de actos administrativos por razón de interés público; cuando estos actos eran declarativos de derechos, se procedía a indemnizar al titular de éstos, justamente como se hace hoy en los supuestos de revocación que hemos incluído en el apartado c) del número 2 de este trabajo. Se trata de una universalización de la expropiación forzosa. Huella de ello existe hoy, por ejemplo, en el artículo 106 de la LJC (indemnización en caso de inejecución de sentencias).

público), de actos declaratorios de derechos, retirada seguida de una indemnización.

La indemnización incluso parece eliminarse en algún supuesto. Nos referimos al artículo 16 del Reglamento de Servicios de las Corporaciones iocales.

El artículo 16 del Reglamento de Servicios, es de una audacia quizá excesiva. Un análisis detenido del mismo arroja el siguiente resultado:

a) En realidad son cinco los supuestos que el artículo contempla:

$\left.a^{\prime}\right)$ Incumplimiento de condiciones en las licencias.

b') Desaparición de las circunstancias que motivaron su otorgamiento.

$\left.c^{\prime}\right)$ Causas sobrevenidas que, de haber existido a la sazon, habrian justificado la denegación de la licencia.

d') Adopción por la Administración de nuevos criterios de apreciación.

$e^{e}$ Caso de licencia otorgada erróneamente.

b) En los anteriores cinco supuestos tienen, como consecuencia, una actuación municipal muy diferente.

$\left.a^{\prime \prime}\right)$ El supuesto $a^{\prime}$ ) parece que actúa ex lege. Pero es evidente que es necesaria una actuación municipal expresa en el sentido de revocar la licencia, es decir, un tercero pide esta actuación, la misma deberá producirse.

b") En los supuestos b') y c) la actuación de la Administración en el sentido revocatorio es un deber. Mas la palabra «deberá» parece que está preocupada en la conducta a seguir frente a la petición de un tercero.

$\left.c^{\prime \prime}\right)$ Los supuestos $d^{\prime}$ ) y $e^{\prime}$ ) dan lugar a una simple posibilidad de actuar revocando.

c) He aquí la consecuencia más importante de la anterior diferenciación: En los casos $d^{\prime}$ ) y $e^{\prime}$ ), la revocación comporta una indemnización de daños y perjuicios. Pero en los tres primeros casos, no hay ninguna indemnización. Esto es perfectamente lógico en el caso de incumplimiento de condiciones. Pero en los otros dos casos se pone un arma verdaderamente fuerte en manos de la Administración. Los Tribunales contenciosos pueden aquí ejercer una función moderadora.

Sobre revocación de licencias véase últimamente sentencias de 4 de febrero y 8 de mayo de 1965, y los agudos comentarios a esta última, de R. MARTín Mateo, en «Silencio positivo y actividad autorizante» $(R A P, 48)$. 
3. LA ALTERACIÓN DE LA TOTALIDAd DEL SISTEMA POR EL ARTíCULO 112 DE LA LEY DE Procedimiento aDMINISTRativo.

Dice este artículo: «Las facultades de anulación y revocación no podrán ser ejercidas cuando por prescripción de acciones, por el tiempo transcurrido u otras circunstancias, su ejercicio resultase contrario a la equidad, al derecho de los particulares o a las leyes».

De este artículo 112 se deduce:

a) Que contrariamente a la dogmática civil, aquí el acto nulo, por graves que sean sus vicios, puede producir efectos y puede ser convalidado.

b) Que en realidad, en ningún caso está la Administración obligada a declarar nulos o anulables los actos viciados (65).

c) Que aparece aquí una interesante manifestación del aspecto prudencial del Derecho.

d) Que como ha dicho OrTolá NAvarro comentando la sentencia de 8 de abril de 1965 (RAP, número 47, página 244), este artículo puede hacer casi imposible la eliminación de actos por motivos de ilegalidad.

e) Que del presente artículo, una jurisprudencia audaz y con fino sentido jurídico podría y debería deducir nada menos que la posibilidad de indemnizar por los daños derivados del ejercicio de las potestades en orden a la eficacia de sus actos. En efecto (y con ello aludimos a los aspectos materiales de la actuación ad-

(65) Acerca de este artículo, S. Martin-REtortillo, en «El exceso de poder como vicio del acto administrativo», en $R A P, 23$, pág. 150, ha dicho que de él se deduce que la Administración no está nunca obligada a retirar los actos de que es autora, cualesquiera que sean sus vicios, y que esto se debe hacer siempre con un criterio de prudencia, justicia y oportunidad. En igual sentido, respecto a planteamiento similar en el Derecho Italiano: PAPALARDO, «L'ecceso di potere amministrativo secondo la giurisprudenza del Consiglio di Stato», en el libro centenario del Consiglio, Roma, 1932, pág. 44. En contra, BoDDA, en «Osservazioni sulla potestà amministrativa di anulamento in ogni tempo degli atti amministrativi illegitimi», en Studi in onore di Cammeo, pág. 96. Hauriou (Précis..., 11. edición, 1927, pág. 383) había postulado una solución del tipo de la del artículo 112 de la Ley de Procedimiento administrativo.

La sentencia de 3 de abril de 1965 ha dicho que el ejercicio de los poderes del artículo 109 no es nunca obligatorio. 
ministrativa expuesta), ¿qué sucede con los derechos reconocidos en los actos afectados por esta actuación? (66). La suspensión de actos no da lugar en ningún caso a indemnización alguna. La revocación por causa de lesión económica parece que tampoco da lugar a indemnización, pues en otro caso, esta sería igualmente lesiva. La declaración de nulidad de acto afectado por alguno de los vicios del artículo 47 o la anulación de actos ilegales, tampoco puede dar lugar a indemnización (67). Sin embargo, sí podría dar lugar a indemnizaciones, excepcionalmente, en los casos de probada buena fe del administrado e imputabilidad clara del vicio a los administradores, sin perjuicio de la indudable acción de resarcimiento de la Administración frente a éstos. $\mathrm{Y}$ ello por una valiente aplicación del artículo 112.

En efecto, si en virtud de la equidad puede suceder que el acto que con criterios meramente formales debería ser eliminado no lo sea, en virtud de igual criterio, podría ser eliminado el acto otorgando simultáneamente una indemnización al titular de los derechos declarados en el acto que se retira (68).

(66) En todo caso, los interesados en la subsistencia del acto anulado o declarado nulo pueden impugnar en vía contenciosa la actuacion administrativa adversa. Cfr. GonZÁ LEZ PÉREZ, en El procedimiento..., págs. 714-717. $\mathrm{Y}$ en tal sentido, se expresa de modo inequívoco el artículo 157 de la Ley general Tributaria.

El único supuesto en el que ya no sería posible una ulterior revisión jurisdiccional, sería en el caso de haberse seguido la via de la lesividad y haberse tramitado el proceso ante el Tribunal Supremo.

(67) Como hemos dicho, hay algún caso de eliminación de actos no seguida de indemnización. Aparte de los actos sancionadores, de lo visto para el artículo 16 del Reglamento de Servicios y de la confiscación prevista en dicho Reglamento, para el caso de rescate de concesiones en que la subasta de bienes, soporte de ésta, falle por dos veces, tenemos la curiosa regulación de los derechos nacidos de la adjudicación provisional en las subastas, derechos cuya existencia reiteradamente ha sido negada ien cuya negativa insiste la Exposición de Motivos de la Ley de Bases de Contratos del Estado); en este último caso, sin embargo, el texto articulado ha creado un verdadero derecho a la adjudicación definitiva al limitar a sólo dos supuestos aquellos en los que puede no convertirse en definitiva una adjudicación provisional. Estos dos supuestos (infracción del Ordenamiento y bajas excesivas que hagan temer por la conservación de las cifras ofrecidas). colnciden exactamente con las nociones de causas de anulacion y de revocacion, respectivamente, que en el presente trabajo han sido expuestas. Pues bien, en ninguno de los dos supuestos cabe indemnización. Cfr. GonzálezBERENGUER, La contratación administrativa, Madrid, 1966, págs. 193 y sigs.

(68) En este sentido, Lavilla Alsina, loc. cit., pág. 73. 
f) Del texto del artículo 112 se deduce, por último, una consecuencia de la más alta significación. Y es (69) ésta: si cualquier ilegalidad que afecte a un acto puede ser desconocida por la Administración, en base a las exigencias del interés público (identificar éste con la equidad no será difícil normalmente), quiere decirse que, en definitiva, este interés prima sobre toda legalidad, y que las razones supremas para la retirada de actos administrativos son las de la oportunidad. Este planteamiento tiene su más cruda expresión si se examina desde el punto de vista contencioso; es decir, ¿qué harían los Tribunales ante una demanda que, apoyada en motivos de legalidad, impugnara un acto administrativo cuyo contenido fuera la negativa de la Administración a anular un acto viciado, si esta negativa se apoyaba en el artículo 112 de la LPA? He aquí nuestra respuesta: cualquiera que fuera el fallo, éste habría de apoyarse, creemos, en razones de oportunidad. ¿No es esto dar una primacía a las potestades revocatorias sobre las anulatorias? (70).

(69) La anulación de oficio de los actos administrativos declarativos de derechos sólo es oportuna cuando se aprecia una manifiesta infraccion de la ley, pero nunca puede fundamentarse en «razones de equidad y justicia» alegadas por la propia Administración. Así lo ha dicho el Consejo de Estado, contra lo que se sostiene en el texto. (Dictamen de 30 de junio de 1960 , expediente 26.519).

(70) Muy otra es la opinión de Trujillo, Quintana y Bolea, que dicen: «Cabe por tanto afirmar que en nuestro sistema la Administración carece de potestad para dejar sin efecto sus propios actos declaratorios de derechos, por motivos de inoportunidad, cuando el acto sea del todo conforme con el ordenamiento jurídico. $\mathrm{Y}$ aun suponiendo que el acto sea ilegal, podrá en determinadas circunstancias «anularlo», pero no «revocarlo».

No debe, sin embargo, olvidarse la posibilidad de que, si bien indirectamente, la Administración revoque sus propios actos declarativos de derechos, por causa de utilidad pública o de interés social, acudiendo al procedimiento expropiatorio, pero, naturalmente, concediendo al sujeto afectado la indemnización correspondiente. Aun cuando en tal supuesto, quizá mejor que la revocación sería preferible hablar de un claro supuesto de «conversión de derechos».

Es lógico que el artículo 112 de la Ley de Procedimiento administrativo impida a la Administración ejercitar su potestad revocatorla, cuando, de hacerlo, infringiese algún precepto legal. La legalidad es, ya lo hemos dicho, el requisito primordial de todo acto, y la Administración no puede en ningún caso desconocerlo por muy oportuno y ventajoso que ello pudiera resultarle. El acto revocatorio de la Administración que infringiese el ordenamiento jurídico, siempre sería impugnable, por los particulares afectados, ante la Jurisdicción contencioso-administrativa» (TRUJILlo, QUINTANA, BOLEA, Comentarios..., I, pág. 908). 